\title{
Dying in the Soviet Gulag for the Future Glory of Mother Russia? Making "Patriotic" Sense of the Gulag in Present-Day Russia
}

\author{
Tomas Sniegon
}

In August 2015, the government of the Russian Federation adopted the Concept of State Policy to Perpetuate the Memory of Victims of Political Repressions. "The decisions to perpetuate the memory of victims of political repression aimed to facilitate the development of partnerships between the state and civil society, the strengthening of intergenerational relationships, the continuity of cultural experience, and the patriotic education of youth," the document says. In this document, the government in fact suggests a centralized concept of memory in regard to somewhat unspecified "political repressions", which should first of all be understood as Stalinist terror or the Gulag. Here, the governmental policy is supposed to be coordinated with similarly oriented efforts of religious and other public organizations, in order to "strengthen the moral health of Russian society" (Russian Government 2015). The concept evolves a previous governmental plan from 2008 concerning the "development of human capital" in Russia, according to which a new Russian national identity is supposed to be based on “active patriotism" (деятельный патриотизм) (Russian Government 2008). Both these documents indicate that the Russian state wants to increase its influence on the construction of memory of political repressions and the development of active patriotism - based on a closer feeling of connection between Russian people and Russian history - more actively than before.

The quest for officially defined and centrally coordinated development of Russian patriotism is not new in post-communist and post-Soviet Russia. As the political scientist Graeme Gill $(2013,214-215)$ has pointed out, the stress on patriotism, seen as loyalty to the state rather than society, has been characteristic for the entire Putin period since 2000. Under Putin, Russia has been positioning itself as a country with its own specific means of democracy that must be based on its own historical and geopolitical foundation, taking into consideration its specifics; only in this way can Russia head towards a better future (Малинова 2015, 146). Putin's predecessor, Boris Yeltsin, had already begun using patriotism as a political tool in order to fill a vacuum around the new regime created by the collapse of the Soviet Union and the Soviet metanarrative.

(C) TOMAS SNIEGON, 2019 | DOI:10.1163/9789004366671_007

This is an open access chapter distributed under the terms of the prevailing CC-BY-NC-ND License. 
Yeltsin had started to do so when the lack of constructive values posed a potential threat to the regime's long-term legitimacy. In the mid-199os, Russian authorities began to change their previous democratic course by seeking an alternative system of values that could unite the Russian society (McGann 1999, 12-27).

What was new in the Russian government document from 2015, however, was the effort to officially connect the newly imposed Russian patriotism with the memory of the Soviet communist terror and repressions. Such a connection, in its very nature, is highly controversial. On the one hand, current Russian patriotism is supposed to express love for Russia and a feeling of "organic belongingness" to the Russian fatherland and its people, which, according to some interpretations, distinguishes it from "anti-patriotic" tendencies, such as support of both Western liberalism and to some extent even communism in Russia (Shapovalov 2008, 124-132). On the other hand, Russian people were set against each other during the Gulag period and Russian society was divided in a way that does not seem to allow the aforementioned concept of Russian patriotism to work from any point of view. The victims, in fact, possessed very few, if any, "patriotic" features, since they died mainly as a result of senseless terror and not because of committing any specific act that would unite various groups of them into one ethnically, ideologically, politically, or religiously homogeneous group that could be ascribed "patriotic" intentions. Another example of the paradox is Joseph Stalin himself; while he was the main perpetrator of "anti-patriotic" political repressions and state-dictated crimes, he has been viewed at the same time as the main force and symbol of the victory in the Great Patriotic War.

The main goal of this study is to analyze how this rather new effort to frame the Gulag memory in Russian post-Soviet patriotic discourse has influenced some crucial sites of memory of "political repressions" in Russia. The focus lies especially on the former firing range of Soviet oppressive forces and execution site in Butovo, one of Moscow's suburb districts; the State Museum of Gulag History in Moscow, the first state museum of this kind in Russia since 1991; and finally the museum and former labor camp Perm- 36 in the Ural region, approximately 1,500 kilometers east of Moscow. These sites of memory have been essential to the memory culture in present-day Russia that has the Gulag as its central point: Butovo and the State Museum of Gulag History are, together with the Solovetskii Stone in front of the former KG в headquarters Lubyanka, the most important sites of memory within the territory of the Russian capital Moscow, while Perm- 36 is the only museum of its kind situated in a former labor camp and representing the repressive character of both Stalinist and post-Stalinist development in the Soviet Union. All three of these sites have 
represented widely discussed cases connected with the memory of the Gulag in both Russian and international media during recent years. As far as I have been able to determine, they represent the "patriotization" of the Gulag memory in a more illustrative and overt way than other Russian places of similar character, including, for example, the Solovetsky Islands, Magadan, Levashovo near St. Petersburg, or the "12th kilometer" near Iekaterinburg.

In her extensive research, conducted during the years 2006-2008, the Polish sociologist and cultural anthropologist Zuzanna Bogumil (2012a, 312-313) has concluded that the places of the Gulag memory have lacked a common meaning in various regions of post-Soviet Russia. As her research indicates, the main actors influencing the meanings of these places between the late 1980s and 2008 were the Memorial society and the Russian Orthodox Church, the latter with constantly increasing influence (Bogumil 2012b; 2012c, and Bogumil et al. 2015). Nonetheless, her study also suggests that, in recent years, a new common "patriotic" narrative of the Gulag may indeed be developing under the control of the state. This is a narrative in which, however, the new nationalist perception of the Gulag memory at the sites in question converges with the Orthodox and Soviet-sentimental way of viewing the traumatic past in order to define Russia's future: the Gulag is not necessarily denied, but the memory of communist terror and crimes is deliberately given meanings other than liberal.

\section{Uneven Past}

Since the collapse of the Soviet Union, the central symbol used for the development of Russian state patriotism has been the Great Patriotic War 1941-1945. The memory of this war has been constructed in order to incite patriotic feelings and emotions in favor of the Russian state and its top leaders. As mentioned, this trend has been rapidly intensified since Vladimir Putin came to power in 2000. Putin has used this memory in order both to strengthen the power of the state under his leadership and to present himself as a true patriot (Wood 2011, 172-200).

On the other hand, during the same time, the places dedicated to the memory of crimes of the Stalinist period, and which focus primarily on the victims, are gradually being deprived of their ability to incite or awaken traumatic and critical emotions that could question the centralized control of the state. In other words, while the first kind of memory means that history is nationalized (Russianized after decades of Sovietization) and traumatized, the second is, on the contrary, systematically de-traumatized and marginalized. 
In this process of traumatization, trauma is seen as cultural trauma, i.e. constructed and not natural or given (Smelser 2004, 35). From this point of view, such collective traumas are, according to the cultural sociologist Jeffrey Alexander $(2012,4)$, "reflections of neither individual suffering nor actual events, but symbolic renderings that reconstruct and imagine them." Therefore, Alexander $(2004,1)$ defines cultural trauma as a trauma that occurs "when members of a collectivity feel that they have been subjected to a horrendous event that leaves indelible marks upon their group consciousness, marking their memories forever and changing their future identity in fundamental and irrevocable ways." As cultural scripts, the truth of these traumas depends not on their empirical accuracy, but on symbolic power and enactment. The trauma process, Alexander $(2012,4)$ also points out, is not rational, but it is intentional. It is people who make traumatic meanings, in circumstances they have not themselves created and which they do not fully comprehend.

This, of course, does not mean that every historical event can become a trauma. However, the crimes of Stalinism, like the Great Patriotic War, undoubtedly fit into what another cultural sociologist, Piotr Sztompka (2004, 159), describes as events with "traumatogenic potential" that can develop into collective/national cultural traumas. Paradoxically, while both the Great Patriotic War and the crimes of Stalinism brought unprecedented terror and suffering to tens of millions of Russian people, the traumatogenic potential of these events has differed substantially in post-communist Russia (Satter 2012). While the memory of the Great Patriotic War continues to be seen as the biggest ordeal of Soviet and Russian history by both the ruling authorities and the society as a whole, the memory of Stalinist crimes has undergone a much more complicated development. This has also been the case among the survivors; their memory of the Gulag has been very problematic, especially with regard to the fact that a number of the Gulag survivors became anti-Stalinist, but not anti-communist or anti-Soviet when Stalin's mass violence ended (Adler 2012).

The memory focusing on Russian patriotic heroism that glorifies the Soviet state, and the memory concentrating on the crimes of the Soviet communist regime, have developed into two different memory cultures of ambivalent character, often contesting each other. Those who have supported the narrative of Russian glory have marginalized the memory of the Gulag, and those who have held the latter memory central have found it very problematic, if not impossible, to celebrate the heroism of the state that was based on Stalinist terror. Thus, the question of how the main actors of these memory processes - current Russian authorities, institutions, and some non-governmental organizations - deal with these contrasting memories is in focus in the present study. 
It is necessary to stress that the study cannot be seen as a comprehensive study of the entire process of memorialization of the worst crimes of the Soviet communist regime. The findings are primarily based on my own visits to the sites of memory in question and other relevant places in Russia, on my interviews with current and former personnel, and on relevant books, articles, and documents.

\section{Russian Heroes versus Soviet Victims}

Since the study deals with "patriotic" memory as expressed through concrete places, it is also relevant to include the main site that symbolizes Russian patriotic memory after the collapse of the Soviet Union: the memorial complex on Poklonnaia Hill in Moscow. Of all places in the former Soviet Union, it is precisely Kutuzov Avenue (Кутузовский проспект) in Moscow and its central part, Poklonnaia Hill (Поклонная гора), that offer the most illustrative example of how post-Soviet Russian leaders want to promote Russian and Soviet history in order to support Russian patriotism through a specific narrative in one place.

The Poklonnaia Hill (literally Bow-Down Hill) site of memory was completed in the first half of the 199os in a part of the Russian capital that is known from the Napoleonic wars of the early 19th century. In May 1995, the first postSoviet victory parade commemorating the Soviet victory over Nazi Germany 50 years earlier was held there. Thus, the new exploitation of the place can be seen as one of the first attempts of the new Russian ruling elite of the 199os to overrule the general disillusionment of the Russian society with the period of "transition" from communism to market economy and political pluralism, turning negative feelings into a new form of patriotism. Within the Russian society, the disillusionment led to what the social anthropologist Sergei Oushakine $(2009,5)$ has called "the patriotism of despair", in which various "communities of loss" produced pessimistic narratives about their suffering within the discourse on the Russian tragedy. Since, as Oushakine has pointed out, the patriotism of despair did not turn these communities of loss against their own country, the memory of patriotic heroism in the most extreme times, for example times of war, could serve as a tool for Russian politicians in their attempts to overcome the contrasts within the demoralized Russian society and at the same time increase their own legitimacy.

The setting of Poklonnaia Hill as it appeared in May 1995, was, as the Swedish historian Kristian Gerner (2011, 307-309) has pointed out, supposed to stress the importance of great people from Russian history. Two war heroes from the 
pre-Soviet and the Soviet past respectively, Mikhail Kutuzov and Georgy Zhukov, were being connected with the first president of post-communist Russia, Boris Yeltsin, the ruler under whose presidency the main memorial and the museum were built. (As a part of commemorative activities in May 1995, a new statue of Georgy Zhukov appeared in Manezhnaia Square, near Red Square.) This connection also emphasized the heroic continuity between the pre-Soviet, Soviet, and post-Soviet eras in Russian history.

The historical narrative of Kutuzov Avenue starts with the building of the Museum-Panorama The Battle of Borodino and the nearby Triumphal Arch of Moscow. These structures were built during the pre-Soviet and Soviet eras respectively, in order to commemorate Russia's victory over Napoleon's Grande Armée in the early 19th century. In 2012, the importance of 1812 to current Russian historical culture was once again officially stressed as Russia commemorated the bicentennial of the battle of Borodino. Borodino was declared to be one of the four most important anniversary events of 2012, which was referred to as "The Year of History".

The text on the statue of Mikhail Kutuzov outside the museum depicts the battle of Borodino in 1812 as "The Patriotic War". This is no coincidence - in 2012, the Museum of the Patriotic War of 1812 opened in central Moscow next to Red Square in the building that used to house the Museum of Vladimir Ilyich Lenin. This clearly illustrates the official stress on "patriotic" history in contemporary Russian historical culture.

Those who start walking from the Museum-Panorama and pass the Triumphal Arch will see the Kutuzov Avenue narrative culminate in the Victory Park on Poklonnaia Hill some hundred meters ahead. The central place there is the Museum of the Great Patriotic War. Thus, the main line of the Kutuzovsky prospekt, focusing on Russian greatness, runs between the Patriotic and Great Patriotic War, or, in other words, between Borodino 1812 and Berlin $1945 .{ }^{2}$

In summer 2014, commemorating the centenary of the beginning of WWI, a monument dedicated to Russian "Heroes of the First World War" was unveiled between the two aforementioned patriotic sites of memory. This happened only a few months after the Russian annexation of the Crimean peninsula. In

1 The other three key events of the year were anniversaries of the Expulsion of Poles from Moscow in 1612, the birth of the former Russian Prime Minister Pyotr Stolypin in 1860, and the foundation of Russian statehood 1150 years earlier. For more, see: Miller <http://www. eupress.ru/uploads/files/H-151_pages>.

2 The "patriotic" battle of Moscow against Polish invaders in 1612 is also mentioned at the main museum exhibition on Poklonnaia hill. However, compared with the events that dominate the narrative in question, the place of this event is imponderable. See: Tsentral'nyj muzei Velikoi Otechestvennoy Voiny. Karta-Putevoditel'. Moscow: Guide-Map Media 2010, 3. 
his speech during the inauguration of the monument, while stressing the courage, combat skills, and patriotism of Russian soldiers, Russian President Vladimir Putin focused on the justification of Russian imperial tendencies and the glorification of wwI, rather than on the tragedy it brought to the Russians and other people (Rutland 2014). In this way, he clearly presented the basic message of the monument.

Setting aside the context of Putin's new offensives on the international stage, the new tendency in 2014 to focus on First World War heroes can be interpreted in two other ways. First, it indicates that those who initiated this proces might have wanted to erase the Soviet communist regime from Russian history. A new focus on the First World War replaced the old one from communist times, when this war was commemorated only through the Great October Socialist Revolution of 1917. At that time, the imperialist war that Russia lost was omitted. According to communist propaganda, the October revolution brought a new world order and gave birth to world history's first state of workers and farmers. All this has been omitted in the present.

This interpretation, however, is only partly true. Communist leaders, especially Joseph Stalin and high-ranking Soviet military commanders from the first half of the 1940s, continue to dominate the Museum of the Great Patriotic War in a context that can only be viewed as heroic and patriotic. ${ }^{3}$ The attention to heroes from the years 1914-1918, however, also shows the official effort to change the understanding of revolutions as progressive steps in Russian history. This has become especially important since the recent wave of "colorful" revolutions in some countries, especially the "Orange Revolution" and the protests in the Maidan Square in the Ukrainian capital Kiev in 2013-2014.

While there is an evident link between patriotic wars on Poklonnaya Hill the Patriotic War of 1812 and the Great Patriotic War in 1941-45, there is no such symbolism linking the First and Second World Wars. This is a tendency that is already well known from the Soviet Union: the description of the latter conflict as the Great Patriotic War means focusing on the suffering of the Soviet state and its people in the period between the German invasion of the Soviet Union in June 1941 and the final Soviet victory in May 1945. Using the term Second World War, on the other hand, would extend the focus to include the period from September 1939 to June 1941. During this period the Soviet Union profited from its alliance with Nazi Germany, doing so in a very "non-patriotic" way through aggressions against its neighbors Poland, Finland, and the Baltic countries Lithuania, Latvia, and Estonia. Besides, the exclusive focus on Soviet

3 Crimes from the Stalin period are mentioned very briefly in one single sentence as "violations of the law", "ungrounded repression against millions of people" and "rough political mistakes". 
suffering during the German invasion excludes the non-European events of the Second World War, especially the battles in China and the Pacific. This has enabled the Soviet Union and post-Soviet Russia to avoid sharing the status of war victim with two other great powers of the Cold War, the United States and China. Only a narrowed focus on the memory of the Soviet suffering during the period of 1941-1945 could help the leaders of both the postwar Soviet Union and post-communist Russia to stress a "patriotic" continuity and connect the Soviet and Russian patriotic identities (Hosking 2002, 162-187).

Developments after 1945 have not found any place in the historical narrative of Poklonnaia Hill either. With regard to Soviet military achievements, this includes two military invasions that, from a Soviet point of view, served to preserve the status of the Soviet Union as a global superpower: the invasion of Hungary in 1956 and of Czechoslovakia in 1968. Thus, the peak of Soviet patriotic memory, the victory in the Great Patriotic War, has not been connected with any positive follow-up or happy ending.

Nevertheless, important references to the postwar communist regime, especially the period between 1964 and 1983, are still visible in the neighborhood, especially on the house at Kutuzov Avenue nr. 26. Here, two postwar leaders of the Soviet Communist Party, Leonid Brezhnev and Iurii Andropov, had their apartments, which is acknowledged by a memorial plaque. ${ }^{4}$

The memorials and the local historical narrative around Kutuzov Avenue clearly show that there is no room for the memory of the victims of Stalinist violence in this historical narrative about the Great Russian state and its heroic military achievements. This is especially noteworthy with regard to the fact that the perspective of the victims is not completely missing there: the memorial sculpture Tragedy of Nations (Трагедия народов), commemorating victims of the mass murder of Jews and other prisoners in the Nazi concentration camps, is situated next to the main building of the Museum of the Great Patriotic War. In 1998, the Moscow Memorial Synagogue, explicitly dedicated to the memory of the Jews who were killed during the Holocaust (Московская Мемориальная синагога - мемориал «Храм памяти евреев - жертв Холокоста») was built in the Victory Park behind the museum.

Why is this kind of memory more acceptable on Poklonnaia Hill than the memory of the Gulag, when the memory of the Holocaust was once even more ignored and marginalized in the Soviet Union than the Gulag memory

4 Those who want to make the narrative of Kutuzov Avenue and Poklonnayi Hill even more complicated may notice that the avenue begins with the Hotel Ukraine, whose symbolic significance, if included into the local historical narrative in question, has become especially sensitive since the Russian annexation of Crimea in 2014. 
(Baranova 2015, see also Gersherson 2013)? The answer seems obvious: the memory of the Jews and other victims of Nazi concentration camps, as presented on Poklonnaia Hill, does not challenge the exposition of Russian greatness and patriotism. The postwar destiny of Soviet prisoners of war who - often side by side with the Jews - were treated extremely brutally by Nazi Germany, but who survived the war only be sent to the Gulag after their return to the Soviet Union, is missing as well. Thus, the Russians, and especially their homeland, Russia, can still be seen exclusively as victims. The perpetrators are exclusively foreign (Tsentral'nyj muzei Velikoi Otechestvennoi Voiny, 2015, 26-27).

In order to see how simplified such an interpretation is, however, a comparison can be made with the Jewish Museum and Tolerance Center in Moscow, opened in 2012. The permanent exhibition at this museum shows, for example, how the Holocaust and the Gulag went hand in hand in the Soviet territory during the World War II. In 1940 and 1941, thousands of Jews were deported to Siberia by Soviet authorities after being labeled as "socially dangerous elements". Paradoxically, these deportations saved the lives of many of the Jews who were affected by them; if left in occupied territories, they would most probably have met the fate of other Soviet Jews who perished during the years of German occupation. The exhibition also pays tribute to active Jewish participation in the Soviet Red Army and shows that among the Soviet Jews, there were not only victims but also heroes of the Great Patriotic War. The parts dealing with Soviet anti-Semitism after the war also show how complex this field actually is (Gorin 2013, 172-202 and 238-246).

However, on Poklonnaia Hill, there is no room for deeper reflections concerning domestic conflicts and tragedies in which Russian/Soviet perpetrators killed and terrorized other Russian/Soviet citizens. In the following pages, I will focus on some of the sites of the Gulag memory and analyze their situation vis-à-vis the official master narrative of current Russia that has been outlined above.

\section{Butovo}

Situated approximately 30 kilometers south of the Moscow city center, the former firing range and execution site of Butovo (Бутовский полигон) was used both as an execution site and as a place for mass burials during the period of the Great Terror in the late 1930s. Thus, Butovskyi polygon is today one of the central mass burial grounds for Stalin-era victims in the Moscow area, with an importance clearly exceeding regional borders. Together with the Solovetsky 
Islands in Northern Russia, Butovo also belongs to the most important sites of Russian Orthodox memory of the Gulag.

Before becoming a firing range for Soviet political police, Butovo had been a horse breeding site. The situation changed when the Soviet security service and political police, the OGPU, and its successor, the NKVD, took over the control of the site and turned its area - approximately two square kilometers into its own "special object". The main wave of killings came during the socalled Great Terror in 1937 and 1938, when the capacity of already established killing facilities and burial sites in central Moscow became insufficient. ${ }^{5}$ At least 20,761 people were executed here between August 8, 1937 and October 19, 1938; it is possible - and even probable - that the real number is significantly higher.

Among the 20,761 documented victims of Butovo were 19,903 men and 858 women aged between 15 to 80 years. The classification of their "crimes" was based mainly on the decision of the Politburo, the highest decision-making organ within the Soviet Communist Party, from July 2, 1937 and the instruction 00447 from June 30, 1937, both of which included a call for the destruction of "anti-Soviet elements".

No matter what they were accused of, the victims never received fair trials and learned about their death sentences only shortly before the executions. The largest number of people executed in one day was recorded on February 28,1938 , when a total of 562 persons lost their lives. Most of the victims were posthumously rehabilitated; 5,595 of them, however, were sentenced for crimes that were not considered to be politically motivated and were therefore not encompassed by the laws for rehabilitations. Nevertheless, even these people, some children among them, were sentenced to death without fair trials. The corpses were buried in 13 mass graves.

By the beginning of the 1940s, Butovo had lost its crucial importance for Stalinist violence in the Moscow region. According to some evidence, it was used on a limited scale until Stalin's death in 1953. After that, it gradually fell into oblivion.

5 In the Soviet capital, Lenin's and later Stalin's regime first killed its opponents - both real and fabricated - in various buildings belonging to security forces near the now infamous KGB headquarters, Lubianka, not far from the Kremlin. The bodies were later buried in cemeteries such as Vagan'kovo (Ваганьковское кладбище) or Donskoe (Новое Донское кладбище). As the level of the Soviet terror increased, however, it became necessary to find new killing and burial places situated outside the highly populated central areas. Therefore, three such places were established: the Butovskii poligon; the Kommunarka; and Liuberetskie meliorativnye polia, the Liuberetsky fields, a place that was not used for mass executions and burials in the end. For more, see Alzo 2007. 
This oblivion, however, was the result of an active policy of ignorance by authorities including the reorganized Soviet secret service, the KGB, which succeeded the NKVD in 1954. Access to the territory of the Butovo firing range remained strictly limited and the site was closed to the public. When the crimes of Stalinism were condemned by new Soviet leader Nikita Khrushchev at the 2oth Congress of the CPSU in 1956, Butovo could have become a site of memory that could provide clear and authentic evidence of the crimes committed during the Great Terror, thus stirring the feelings of its visitors against that terror. Instead, in 1957, the Supreme Soviet issued a decision that allowed employees of the KG B to build summerhouses and establish a group of cottage owners, Dachnyi kooperativ, in Butovo. KGB personnel were allowed to build and own cottages only dozens of meters from the mass graves, though it was forbidden to dig deeper than $5^{0}$ centimeters. The status of Butovo as a secret "special object" owned by the Soviet and later Russian security service ended first in 1995.

The Soviet attitude to the memory of victims of Stalinist terror began to change during the reform period of Perestroika in the late 1980s; in October 1988, the Congress of Peoples' Deputies decided that those who were unjustly killed during the terror period should be rehabilitated. This decision was confirmed by the Politburo soon thereafter. In the case of Butovo, however, the change was slow (Alzo 2007).

The KGB was indeed ordered to begin searching for mass graves. At the same time, the communist regime still existed and the findings were not supposed to undermine its legitimacy. Moreover, the amount of work connected with the aftermath of Stalinism was enormous. The lack of capacity from state organs, however, turned into an advantage for those who wanted to reveal the history of Butovo when non-governmental organizations could be included in the research for the first time. The most important of these was the Memorial society, established as an organization driven by "moral imperative" and aiming to spread knowledge about the tragic past, promote human rights, and protect the memory of the victims of the regime in Soviet and later Russian post-Soviet society. As Nanci Adler $(1993,47)$, a Russianist specialized on research of the Soviet empire's oppression and terror against its own population, has pointed out, Memorial has fulfilled several functions since its establishment: it has served not only as a historical enlightenment society but also as a human rights movement, a social organization, and a political organization. As the journalist and researcher specialized on the Soviet Union David Sutter $(2012,37)$ has indicated, since Memorial had quickly established its branches in 110 cities, the Soviet authorities feared it could become a base for an alternative political party. For similar reasons, Memorial became unpopular among those who 
opposed Russian liberal ideas (more than 25 years after its foundation, Memorial still faced similar problems from the Russian leadership headed by President Vladimir Putin).

Finally, the fall of the Soviet Union in December 1991 made a definite change in the situation. Suddenly, the communist ideology was no longer an obstacle in the process of coming to terms with the tragic past.

\section{From State Indifference to Orthodox Custody}

Butovo as a site of mass murders was first publicly revealed by journalists. The gate of the Butovo shooting range finally opened in June 1993. However, during the years following the collapse of the Soviet state, Butovo became clear proof of the inability of the Russian post-Soviet regime to establish a new coherent historical narrative about the Gulag in order to define and develop new Russian democratic values. The lack of direct, sustainable official intervention aimed at preserving various sites of the Gulag memory was obvious on the federal, regional, and local levels (Anstett 2011). Since that time, the regime has increasingly leaned on the concept of a "Russian idea" where the memory of the Gulag has not actually gained any significant position. ${ }^{6}$

In 1993, the first memorial stone dedicated to the memory of the victims of the crimes of Stalinism was installed near the Butovo mass graves. The stone made the history of this place more visible than before; the text briefly explained the identity of the perpetrators - as belonging to the political and secret police, the NKVD, and the forces of the Ministry of State Security, the MG B - while the victims remained unspecified, described simply as "many thousands of victims of political repressions" from the period 1937-1953. The monument was initiated by the Memorial society and placed next to the main road leading to both the former firing range and the cottage area of former employees of the KGB. At that time, the KGB successor organization, the FSB, lost interest in allowing its employees to build new cottages. It became unwilling to maintain the place any longer; therefore, the territory including the mass cemetery in Butovo came into the custody of Moscow's regional authorities. Archaeological excavations in 1997 definitively confirmed the site's tragic past.

Under the new system of market economy, some of the surrounding buildings changed owners and the authorities started to plan ways to exploit the place commercially. These plans counted on building a huge apartment block in the memorial zone, only a few dozen meters from the burial sites. Through

6 Compare with Gill (2013, 43-78). 
such steps, both the new Russian state and the regional institutions proved that they did not see the former Butovo execution site as a site of memory that would be important to save and protect for the future (Alzo 2007, 173). ${ }^{7}$ Such a disrespectful attitude provoked protests from both the Memorial and the Russian Orthodox Church, whose patriarch even intervened with the mayor of Moscow and urged him to stop the plans. When the opponents of the building plans indeed managed to stop the construction work, even the regional authorities lost their interest. Since Butovo fell into this situation at the time when the new form of patriotic memory became visible at the Poklonnaia Hill, this proved that the memory of the Gulag did not fit into the current plans for official "patriotic mobilization".

Thus, the Russian Orthodox church, together with the Memorial society, was in fact forced to take care of the place if it wanted to preserve the memory of Stalinist terror there at all, rather than allow the state to let the memory of the communist regime's crimes in Butovo fall into oblivion again. In the absence of a clearly defined state concept of the Gulag memory, however, the civic- and liberal-oriented concept of the Gulag memory developed by the Memorial society differed substantially from the Orthodox concept of memory of the crimes of Stalinism. These two concepts faced one another in Butovo.

The Russian Orthodox Church was given priority by the state and obtained the custody of Butovo in 1995. This custody did not yet entail an exclusive right. The church took the initiative to preserve Butovo as a site of memory due to the fact that a number of the victims were of the Orthodox faith. Of the 20,760 officially identified victims from Butovo, almost 1,00o were Russian Orthodox priests. On May 27, 2000, the first church service in Butovo was held under an open sky by Alexei II, the Patriarch of Moscow and the entire Russian Orthodox Church.

The Russian Orthodox Church was becoming more influential, but there were still other options. When the new State Museum of Gulag History was being planned and realized in Moscow in 2001, a connection between this museum and the Butovo site of memory was discussed. If such a step had been realized, the state would have kept its control over Butovo to a much greater extent than it finally did. Moreover, the Russian Orthodox Church wanted to strengthen its own way of commemorating the victims of the Gulag, in order to make it more stable and long-lasting than the changing policies of the state

7 However, it should be noted that the situation - such an ignorant attitude - was not the same in the entire territory of the Russian Federation. In 1996, for example, a huge, 15-meter high monument called Mask of Sorrow, made by the Russian sculptor Ernst Neizvestny, was unveiled in the city of Magadan in eastern Russia with the financial help of Russian government as well as seven Russian cities. 
and at the same time less "neutral" and "politically correct" than the way suggested by the Memorial society. Since the majority of the visitors were Russians who belonged to the Orthodox Church, the church wanted to show that Butovo as a site of memory reflected the beliefs of these people first of all ${ }^{8}$.

At the same time, the state authorities once again confirmed their ambiguous attitude to the place; in August 2001, the authorities of the Moscow region declared Butovo a historical and cultural memorial of local importance (Alzo $2007,108)$. The classification of the site as a place of "local importance" recognized neither the historical significance of the site to the entire Russian society nor its importance within an international or perhaps even global context.

Finally, in 2002, the church took its decisive step by making a deliberate choice not to seek the partnership with the state and to develop the memory site quite according to its own intentions and wishes. It established its own "autonomous non-commercial organization Memorialnyi tsentr "Butovo" (Мемориальный центр «Бутово»). The center was created with the ambition to coordinate the commemorative efforts of state, religious, and public organizations; in fact, its autonomy meant that the church had the main power to decide who would be commemorated in Butovo and how 9 .

\section{The Triumph of a Martyr}

The symbolic expressions of Orthodox memory in Butovo are based on four main objects: two crosses and two churches. The first cross and the first church were placed right on the territory of the former killing field already in the middle of the 1990s. The second church and second cross - both larger in scale were added in 2007 .

The first, small wooden church was built already in 1996. Since 2007, when Russia commemorated the 7oth anniversary of the beginning of the Great Terror, another church, the new Church of the Resurrection and the Holy New Martyrs and Confessors of Russia, has dominated the place. This was moreover the very first church in Russia to be consecrated after the reunion of the Russian Orthodox Church and the Russian Church Abroad in the same year. Between the 1920s and 2007, the Russian Church Abroad had existed only as an émigré outside the Soviet Union.

As in the case of the first wooden church, the first and smaller cross, erected in 1994, was supposed to symbolically mark the place where the mass graves

8 Author's interview with Igor' Garkavyi, 13 October 2016.

9 Ibid. 
had been situated. The second, larger cross, also installed in 2007, has gained a more far-reaching symbolic importance. It has created a symbolic connection between Butovo and the Solovetsky Islands, a place in the White Sea in northern Russia, approximately 1,400 km from Moscow or almost $900 \mathrm{~km}$ from Sankt Petersburg, where one of the very first labor camps for political opponents of the communist regime in the Soviet Union was created in 1923. The camp was established at Solovetskii Monastery (Соловецкий монастырь). ${ }^{10}$ In 2007, a so-called Solovetskii Cross was brought by boat from the northern islands and erected next to the new Church of the Resurrection and the Holy New Martyrs and Confessors of Russia.

As political scientist and journalist Veronica Dorman (2010, 431-436) points out, the Russian Orthodox Church can be seen as an important framework for the formation of Russian post-communist identity - as an heir of the Byzantine tradition that links religious confession with national identity, as an eminent victim of the Revolution representing pre-revolutionary past, as the only institution spanning the entire territory of the former USSR, and finally as the designated guardian of mores, customs, and morals in Russia today. Nevertheless, the ambition of the church has been even higher; in fact, the church had aimed for what Dorman calls privatization of memory. From this point of view, the crosses were supposed not only to link two former sites of Stalinist terror, but also to mark the new dominance of the Orthodox interpretation of the Gulag. While the first symbolic connection between the Solovetsky Islands and the Russian capital of Moscow to concern the memory of the Gulag had been marked by the Solovetsky Stone brought from northern Russia to Lubianka (formerly Dzerzhinskii) Square and placed in front of the KGв headquarters to commemorate the zeks, innocent laborers tortured in the camps, this second connection predominantly - although not exclusively - focused on religious victims.

In replacing the statue of кG в founder Feliks Dzerzhinskii in central Moscow with the Solovetskii Stone, the Memorial society had used the symbolism to develop the concept of human rights for all citizens of the country, no matter their political, ethnic, or religious belonging. The Memorial had chosen the date of October 30, 1990 for the erection of the Solovetsky Stone in order to commemorate in parallel the initiative by political prisoners on October 30 , 1974 to declare that specific day the Day of Political Prisoners in the Soviet Union. One year after the Solovetsky Stone was installed in Lubianka Square, the Supreme Soviet in Russia officially established October 30 as the day of

10 As the only site of the Gulag memory, the Solovetskii Monastery has been protected by UNESCO since 1992 as a part of the world's cultural heritage. 
Remembrance of the Victims of Political Repressions. The Russian Orthodox Church, on the other hand, constructed a different meaning of the Gulag past. At the center of this interpretation was not a zek but a martyr (Bogumil, Z., M. and D, Harrowell, Dominique and Elly 2015, 1416-1444).

The religious connection between the Solovetsky Islands and Butovo, however, was not unproblematic. The historical character of the Solovetskii Monastery as a site of memory of the Gulag was different from that of Butovo, since the Solovetskii Monastery was owned and administered by the Russian Orthodox Church already before it became a part of the Soviet communist terror. Thus there was no need to construct a completely new Orthodox memory of the communist terror there after the fall of the Soviet Union as was the case in Butovo, which had previously been a non-Orthodox site. Nevertheless, the commemorations of the 7oth anniversary of the beginning of the Great Purges in 2007 created a connection not only between these two places, the Solovetsky Islands and Butovo, but also with some canals that were built during the Soviet Gulag period.

The Solovetskii cross was namely brought from the Solovetsky Islands to Butovo in a spectacular way, by a boat on Russian rivers, thus symbolically connecting places of imprisonment (Solovki), exploitation (canals), and execution (Butovo)(Dorman 2010, 432). On the final stage of its journey, the boat even passed the very center of Russian political power, the Kremlin.

The 12-meter-high wooden Solovetskii cross was erected in Butovo on August 8 in order to commemorate the beginning of the mass executions that had started the same day 70 years earlier. Some weeks after the anniversary, on October 30, 2007, the connection between the Orthodox memory of the Gulag and the highest Russian political power reached its peak. On that day, which was the Day of Remembrance of the Victims of Political Repressions (i.e. the date of originally secular memory of the Gulag), Russian President Vladimir Putin appeared in Butovo together with Moscow Regional Governor Boris Gromov to attend a religious service hold by Patriarch Alexis II. This was the first time the head of the Russian Orthodox Church was present in Butovo on October 30, and the first time the head of the Russian state took part in a commemorative ceremony for the victims of Soviet terror. Even Human Rights Commissioner Vladimir Lukin was present. The day finally confirmed the Orthodox superiority concerning the interpretation of the Gulag memory at Butovo. All commemorative activities, no matter if their basis was religious or secular, were now held under the leadership of the Russian Orthodox Church.

The same occasion, however, also proved how controversial the connection between the leaders of the Russian state and the Russian Orthodox Church could become in terms of using the Gulag memory in support of the current 
Russian political regime. When President Vladimir Putin visited the site of memory in Butovo, he met both Patriarch Alexis II and the senior priest of the church, Kirill. On the one hand, Putin paid tribute to the victims and stated that the victims of the 1930 s were "the pride of the nation" since they had not feared to speak their mind. On the other hand, however, Putin (2007) added that "in honoring the memory of past tragedies we need to base ourselves on the best things that our people have accomplished. We must combine our efforts and promote Russia's development. We have everything we need to do so." The president never admitted any responsibility on behalf of the Soviet/Russian state, nor did he mention his own past as a KGB officer. The same day, the Russian Orthodox Church (2007) issued a statement that claimed that the crimes of the communist era should be commemorated with prayers and not political meetings. According to this approach, and in keeping with Christian tradition, the "proper form of memorialization" is observed when "people without any meetings and demonstrations go to the places of execution or other places of memory and take part in collective prayer."

The Russian Orthodox Church has included Butovo among places described as "The Russian Golgotha”, i.e. places of the highest religious importance. Other such places are, for example, the aforementioned Solovetsky Monastery and Ganina Iama (Ганина Яма) near Yekaterinburg, where the remains of the last Russian tsar, Nicholas II, and his family, all murdered by the Bolsheviks in 1918, were discovered in the 1970 .

The term "Russian Golgotha" has been used to symbolically link the suffering of Russian Orthodox victims to the Golgotha near Jerusalem where Jesus was crucified. In addition to its religious dimension, the term "Russian Golgotha" has an ethnic character in terms of Russianness. The usage of the Russian word Russkaia and not Rossiiskaia Golgotha indicates that it does not pertain to non-Russian victims of Soviet communist terror in Butovo, such as members of the international communist movement and foreign enthusiasts who came to Soviet Russia in order to help in its communist development and who, too, were executed in Butovo. Citizens of countries such as Germany, Poland, France, the usA, Austria, Hungary, Romania, Italy, Yugoslavia, Czechoslovakia, Turkey, Japan, India, and China who were killed at Butovo have thus been excluded from such an ethnically dominated concept of Gulag memory.

Moreover, there were many non-Orthodox people among the victims, including Catholic believers, Muslims and Jews. A large group of victims of Stalinist communism in Butovo were the communists themselves, i.e. those communists who were murdered by their own regime and who, some of them fanatic atheists, would have disliked being commemorated through any reli- 
gious traditions. ${ }^{11}$ As many as 1,200 victims of Butovo were executed only because they were disabled and thus found to be inferior. This aspect of the Great Terror - the killing of people on the basis of their physical disabilities - has received little attention from scholars so far, even though the treatment of the disabled indicated that Butovo was not the only place in the Soviet Union where people with disabilities suffered and died during the Gulag period.

Since the church took over yet another, smaller site of the Gulag memory in the Moscow region, Kommunarka, it is interesting to compare the style of commemorations in these two places, especially with regard to the memory of religious and non-religious victims.

Kommunarka served in the 1930 as a dacha, summerhouse, of the OGPU (the predecessor of the NKVD) chief Genrikh Yagoda. More than 10,000 victims of the political terror of the late 1930s were buried there, including Iagoda himself. These victims, however, had very little to do with Orthodox belief; they were prominent members of Soviet state institutions and security forces of that time, i.e. those who first supported the terror but who later became its victims. They were, however, executed not because of their previous involvement in or support of the mass murders, but because they fell into disgrace.

Today, the Orthodox church in Kommunarka prays for these victims - who came from within the Soviet Communist Party. The church representatives have solved this paradox in the following way. They keep praying for the victims because "despite the fact that they used to be communists, nobody knew what was going on in their heads when they came face to face with death while waiting for the execution"12. From this point of view, the local attitude of the church in Kommunarka seems to be more inclusive than the one in Butovo.

Butovo has even been described as a sacred place, similar to the "fields of Russian glory like Borodino" (Alzo 2007, 175). The commemoration of the sufferings of victims of Stalinism as part of "sacred Russian glory" clearly illustrates the nationalist tendencies of the Russian Orthodox memory culture.

Moreover, by declaring its victims martyrs, or more exactly New Martyrs according to the Orthodox tradition, the church has radically changed the meaning of their suffering. The term New Martyrs is not new. Originally, New Martyrs or Neomartyrs were those Orthodox Christians who were killed by people of other religions or by atheists. In the new Russian context, however, it refers to people who suffered and died as the result of Soviet anti-religious persecutions. The Russian Orthodox Church has commemorated these victims through an unprecedented wave of canonizations, starting during Perestroika in the

11 For more about the proportions of Butovo victims, see: Alzo (2007, 96-144).

12 Author's interview with Ermogen, priest in Kommunarka, 11 October 2015. 
late 1980 s. While the church had canonized approximately 300 people before 1988, the number exceeded 2,00o by 2010 . Butovo has played an important role in this new policy of the church (Hyldal Christensen 2016).

More than 330 of the 936 church victims at Butovo have been canonized. While the reasons for their executions were often absurd and based on false accusations of espionage, terrorism, and hostility to the Soviet regime, the church has interpreted their suffering as a sacrifice for a higher purpose; as martyrs, they suffered not only because they were brutally deprived of their basic human rights, but primarily because of their faith and dedication to their Russian Motherland.

Only the names of the victims who belonged to the Russian Orthodox Church have been presented individually on large boards that hang on a fence surrounding the former killing field in Butovo. The non-religious victims have not been mentioned by name until now, with one exception: in 2014, a new board was installed near the main entrance to the seven hectare memorial area, containing the names of twelve Russian generals from the First World War who were killed in Butovo in the late 1930s. Moreover, hundreds of officers from the Russian Army during the period 1914-1918 are specifically mentioned. This makes the army group from the First World War the second most visible entity after the religious martyrs.

In recent times, the Russian Orthodox Church seems to be more aware than before of the problems involved with the hierarchization of victims at Butovo. In a new park of memory, built in Butovo to commemorate the 7oth anniversary of the Great Terror in 2017, the names of all victims are fully specified, not according to religious or other hierarchy but in alphabetical order. The Russian Orthodox Church had long since received requests to list all victims, rather than only religious victims, from the victims' relatives, but it came about first in 2017, two years after the new state concept of the Gulag memory. According to the Director of the Butovo Memorial Center Igor' Garkavyi, the new park will finally avoid "competition of memory"13. This is happening despite new moral problems for the church, especially the problem of those victims who were executed for criminal and not political activities (and who have therefore not been rehabilitated) being listed side by side with the New Martyrs. The church, according to Garkavyi ${ }^{14}$, now recognizes even those people as victims who should be commemorated; although they might have committed crimes that were not merely "politically invented" by Stalin's regime, they were not punished after a decision based on a fair trial. In a similar way, the memory of

13 Author's interview with Igor' Garkavyi, 13 October 2016.

14 Ibid. 
the Gulag victims is supposed to be commemorated not only by prayers in both Orthodox churches, but also by a new museum.

However, the museum is now being spoken of as the "Russian Golgotha" museum focused exclusively on victims of religious repressions. The current debate about it illustrates how the Russian state has effectively handed over custodianship of the Soviet past and responsibility for commemorating and mourning the victims of Soviet state terror to the Russian Orthodox Church, while secular civil society organizations are being excluded at the same time. (Fedor and Sniegon 2018).

Of all the places included in this study, Butovo has most evidently shown the formation of a new, patriotically oriented memory of the Gulag in today's Russia, with the concept of "Russianness" founded on religious and ethnic bases. In other places, the adjustments to the new governmental concept of the Gulag memory are visible in different ways.

\section{The State Museum of Gulag History in Moscow}

The State Museum of Gulag History in Moscow was founded in 2001. It was created through the initiative of Anton Antonov-Ovseenko, a historian who himself had once been a prisoner of Stalin's labor camps. The permanent exhibition opened in 2004.

The Gulag museum in Moscow received the most prominent location of all museums and sites of memory dedicated to the victims of Stalinism - with the exception of the Solovetsky Stone in Lubianka Square. ${ }^{15}$ It was constructed on Petrovka Street at the very heart of the Russian capital, next to the building of the attorney general and not far from the Bolshoi Theater, the Russian Parliament and the former кG в headquarters Lubianka.

This first Gulag museum that existed between 2004 and 2015 was visited by approximately 50,000 people annually, one-third of them foreign tourists. Thus, the number of visitors was allegedly slightly higher than the number of

15 The Solovetskii Stone is a monument dedicated to the victims of Stalinist terror, in the form of a stone that was brought to central Moscow from the Solovetskii prison camp on the Solovetsky Islands. It was placed in front of the KG в headquarters Lubianka on October 30, 1990 in order to support a movement for the declaration of a Day of Political Prisoners in the then Soviet Union. Even though the cross in Butovo and the stone both came to Moscow from the same location, the meanings of both sites of memory are different as the stone primarily belongs in the context that links the Gulag memory to the human rights agenda. 
those who visit the former execution site in Butovo. ${ }^{16}$ In spite of this, the figure seems conspicuously low, considering the fact that Moscow is the capital of a country with almost 150 million inhabitants and that the city itself has 12 million inhabitants. Nevertheless, this might change in the event that the new museum, with its new and recently opened exhibition, manages to become a part of the educational program of Moscow's school classes. Such a development is now being negotiated ${ }^{17}$ (Romanov 2015).

The State Museum of Gulag History has had a lower status than the federal Museum of the Great Patriotic War on Poklonnaia Hill since it has been connected with municipal institutions of the City of Moscow and not with state organs of the Russian Federation. The Gulag museum has been supported and supervised by Moscow's own Department of Culture.

The initially small scale of the museum and the fact that this important exhibition was established as late as ten years after the fall of the communist regime in the Soviet Union showed that the demand for such a museum from the state and municipal authorities was low during the 199os. The State Museum of Gulag History was not the first museum in post-Soviet Russia dedicated to the memory of the crimes of Stalinism. In 1996, a permanent exhibition dedicated to the crimes of communism had been opened in Moscow at the Sakharov Center, a museum and cultural center named after the well-known Soviet dissident and nuclear scientist Andrei Sakharov.

Why, then, were two such exhibitions needed in Moscow? There are two important differences between them. Firstly, the Sakharov Center is linked to the dissident tradition and is deliberately a non-governmental, i.e. not stateowned, organization. Secondly, its exhibition is very critical of the entire period of the Soviet communist regime and does not focus solely on the period of Stalinist terror. This means that the Gulag memory as presented by the Sakharov Center has been substantially more closely connected with liberal political values than the same memory as presented by the Gulag museum. ${ }^{18}$

The Gulag museum has focused primarily on the victims. It has a documentary archive and a collection of personal belongings and works of art made by

16 Since the entrance to Butovo is free of charge and the area is open to all visitors, it is difficult to find exact visitor figures.

17 Author's interview with Roman Romanov, 12 October 2015.

18 In December 2014, the Sakharov Foundation was declared a "foreign agent" in accordance with Russia's new foreign agent law, introduced in 2012. This status automatically denies any "patriotic" character of institutions labeled with it, as seen from the point of view of current rulers of the Russian Federation. The Gulag museum, on the contrary, cannot be placed in the same situation due to its character as a state museum. 
former Gulag inmates, as well as works by contemporary artists who have tried to come to terms with this traumatic past through their art.

The State Museum of Gulag History has faced a very specific problem: from the beginning, it has had to deal with the same questions as the Sakharov Foundation about its attitude to perpetrators, victims, questions of patriotism, and human rights in Soviet and Russian society. However, at the same time, it has had to act within the framework of state policies with their varying relationship to liberal political values. In its first permanent exhibition situated on Petrovka Street, it developed an interpretation of the Gulag that, on the one hand, does not deny the crimes of the Stalinist regime, yet, on the other hand, does not immediately connect the period of the Gulag with human rights activism, i.e. with the effort to increase respect for human rights and civil society in post-communist Russia in general and Russia under Vladimir Putin in particular. Thus, the difficulties are not connected to the facts and discussions about the Gulag period itself, but rather to the question of what specific meaning the Gulag should have for post-Gulag Russians. ${ }^{19}$

This solution of the first permanent exhibition also reflected a unique feature of the Soviet and Russian post-terror society: the case of the Gulag in which not all survivors - after being released from the camps - remained critical to the regime that had sent them and their relatives to camps and prisons. While many of these people became critical towards Joseph Stalin, Lavrentii Beriia and other Soviet leaders who were responsible for mass murders between the 1930s and early 1950s, a significant number of them were not equally critical towards the Soviet communist system in general. In this way, they remained convinced Soviet patriots.

The Gulag survivors who have such an ambiguous relationship to the Gulag memory belong to a category that Nanci Adler (2012, xii) describes as loyalist Gulag prisoner or survivor. As the American historian Stephen Cohen (2012, 95) points out, those returnees from the Gulag who blamed Stalin but remained pro-Soviet were in a majority in the 1950s and 196os. Alexander Etkind (2013, 12), a literary historian who focuses on research of memory and cultural development in Russia, has described the current expression of this paradox as warped mourning. However, this paradox included many more than just the direct survivors. As the Soviet regime compromised the ideas of socialism, the human victims of the Soviet experiment were mourned alongside the ideas and ideals that vanished in the experiment. The mourning of people who were murdered for their ideas, ideas which also disappeared in the violence, created

19 For more about these discussions, concerning both definitions and interpretations of the Gulag in Russia, see, for example: Khlevniuk and Belokowsky (2015, 479-498). 
a very paradoxical double-mourning that paralyzed the efforts to come to terms with the violent Soviet past. That contributed to the fact that no hegemonic regime-critical narrative of Stalinist terror ever developed in the postStalinist Soviet Union. This in turn has been one of the reasons why such a widely recognized master narrative, oriented to promote liberal democratic values and influence a large part of the Russian society, is still to a large extent missing in post-Soviet Russia, where those who support such an interpretation of Stalinist crimes are still a minority.

The founder of the State Museum of Gulag History, Anton Antonov-Ovseenko, could be included in the loyalist category. He was the son of the revolutionary Vladimir Antonov-Ovseenko, who, after fighting against the tsarist regime, became an important figure during the Bolshevik revolution of October 1917 as a leader in the storming of the Winter Palace in Petrograd. Afterwards, Vladimir Antonov-Ovseenko served as a Bolshevik commander on several fronts in the civil war. During the period 1922-1924, he was a political chief of the Red Army. After spending some years in Soviet diplomacy, he became chief prosecutor in 1934 and later, in 1937, People's Commissar for Justice of the Russian Soviet Socialist Republic. In 1938, Vladimir Antonov-Ovseenko was arrested and executed.

The wife of Vladimir Antonov-Ovseenko, and the mother of their son Anton, committed suicide in one of Stalin's prisons. Anton spent a significant part of his youth as a Gulag prisoner, but because of his family heritage, he did not turn against all the political and ideological values for which his father had once fought. Becoming a historian, he saw his mission primarily as "unmasking Stalin's hangmen and their heirs in the KGB" (Cohen 2012, 137).

This is evident from a book published in the West in 1980 . There, Antonov-Ovseenko $(1981, \mathrm{xvi})$ primarily blames Stalin and "the butchers, the informers, the pogromists" but never the communist system as a whole. The circumstances of his life in the Soviet Union, which was still led by Leonid Brezhnev at that time, must be taken into an account. Nevertheless, he did not significantly change his view concerning the communist revolution and system even after the collapse of the Soviet Union, which was also reflected in "his" exhibition. In fact, the personality of the founder and the very existence of the Gulag museum (and, of course, its exhibition) were inseparable. Stephen Cohen $(2012,166)$, a friend of Anton Antonov-Ovseenko, has even described the museum as Anton's museum. 
The Gulag museum's first permanent exhibition did not express any kind of regret from the Russian state and did not provoke any self-reflection from the Soviet/Russian society. The documents and artifacts that were exhibited showed both the brutality on the part of the decision-makers and the horrific suffering of the victims. However, crucial questions remained unanswered. How was Stalin possible? Who were those millions of "ordinary Russians" who made his terror possible and why did they do so? And what about the rest of the Russian society? Last, but not least, what relevance is the memory of the Gulag supposed to have in Russia today?

The international dimension of the exhibition should be examined critically as well. The Second World War was still referred to as The Great Patriotic War. The foreign victims were sporadically mentioned, but the Gulag was still treated as a domestic and not an international crime. A former Czechoslovak army general who was mentioned specifically, Ludvík Svoboda, was portrayed exclusively as a Gulag victim without any mention of his Stalinist activities in the late 1940s when he, as the Minister of Defense of Czechoslovakia, helped the Communist Party of Czechoslovakia seize absolute power in the country, or when he, in 1968 as the president of Czechoslovakia, became one of the leading Czechoslovak officials who assisted the Soviet Union in reconstituting its power in Central Europe after the defeat of the so-called Prague Spring reform process. Svoboda and some other examples illustrate that the museum's way of expressing the trauma of Stalinism in its exhibition was not an attempt to represent the entire communist period as a trauma, either to the Russian public or to an international one, even though it was, beyond any doubt, constructed to condemn the worst crimes of Stalin's dictatorship. Thus, it did not challenge the Putin regime's construction of continuity between Soviet and Russian post-Soviet patriotism - whenever needed by the regime - by introducing "foreign" liberal values into the Russian Gulag memory culture, as was done in the case of the Sakharov Foundation.

In October 2015, the State Museum of Gulag History found its new location outside the Moscow city center, not far, in fact, from the Butyrka Prison, which became "famous" during the Gulag period and which even today serves as a prison, making it a site of memory with limited access. The move of the Gulag museum had been prepared already during Dmitrii Medvedev's presidency in 2011 with the help of the City of Moscow authorities. However, gazeta.ru (2015) reported that when the museum was opened on October 30, 2015, which was the day of Remembrance of the Victims of Political Repressions in Russia, none of the Russian top politicians joined in the opening ceremony.

The new museum is about four times bigger than the first one, with much better technological equipment and new facilities for seminars, research, and 
other activities. These new opportunities can be seen as a clear improvement. Compared with the first exhibition on Petrovka Street, the visitor is presented with a much more impressive experience based on empathy with the victims. However, some aspects that avoid a collision between the meaning of the Gulag as presented by the museum and the politics of Gulag memory as practiced by the current Russian authorities still remain (Hardy, forthcoming).

First, the Gulag is seen as a problem of the Soviet past and not the Russian present. As stated during the opening, the museum is supposed to be "devoted to research, discussion, and public manifestation of the era of Stalinist repressions" (Moscow City Website 2015). But while the Gulag period has been extended backward to 1918 , the dimension after 1953 remains underdeveloped. ${ }^{20}$ In fact, even though the term Gulag is included in the museum's name, its content and meaning are not explicitly elaborated. Instead, the continuous dominant focus on the victims and the Gulag as a closed chapter of Soviet history leaves a number of disturbing questions about the entire Soviet system, the relationship between society and mass violence, and the Gulag's overall legacy unanswered and even unspoken.

Second, the focus on foreign victims of the Soviet terror is insufficient in the museum's narrative, especially concerning groups from territories annexed by the Soviet Union after the end of the Second World War. This lack is particularly evident when the exhibition is compared with the recently closed exhibition at the former Gulag camp Perm-36, where similar problems related to nationality were not omitted to as great an extent. The focus at Perm-36, however, contributed to it being labeled as a "foreign agent" and accused of supporting "fascists" by the current Russian regime, as will be described later.

Based on these two aspects, the exhibition described as the "national memory of the Gulag" seems highly problematic, since the discussion about the memory of the Gulag, in fact, plays a marginal role here. The timeline presented on the floor of the museum's main hall portrays the Soviet period as a problem, while the Russian post-Soviet period appears to be a solution, though without any mention of the new Russia's inability to include the Gulag in the construction of its new identity. The last screen in the last room of the exhibition shows former Russian President Dmitrii Medvedev visiting the site of the Gulag memory at Magadan and Vladimir Putin visiting Butovo, thus giving both of them a prominent place in the meaning of this "national memory" of the Gulag. This is a clear indication that the Gulag can, indeed, be included in a "patriotic" narrative in the sense that the current Russian leadership has been developing during recent years. 


\section{Perm-36}

The difference between the two processes of trauma construction mentioned previously - the traumatization of the crimes of Stalinism in order to condemn the period of the most cruel communist violence and the traumatization of the entire communist period in order to construct new liberal democratic values - is also clearly visible in the case of the Perm-36 museum in the Ural area of the Russian Federation. Compared with the aforementioned sites of memory, situated in Moscow, the attitude of the state authorities has been very different here.

The Museum of the History of Political Repression, Perm-36, situated at the former Soviet forced labor camp Perm-36 in the village of Kuchino, approximately 120 kilometers from the city of Perm, occupies a very special position within the Russian post-Soviet context. It was constructed on a site that was previously used as a unique Gulag and post-Gulag labor camp. The camp was put into operation during the era of Stalinism in the 1940 s as a camp for prisoners who were forced to work in nearby forests. While many other camps at that time were made of wood and served only temporarily (after fulfilling their mission they were abandoned and destroyed), the barracks of this camp were made of bricks and built to last a long time. This was one of the reasons why the camp was not demolished after Stalin's death. Instead, it continued to serve as a labor camp, but now for prisoners of a different kind.

Its new prisoners were former employees and officers, some of them highranked, of Soviet judicial authorities and the Ministry of Internal Affairs. They were charged with crimes committed during the Stalinist period. Paradoxically, some of these prisoners had even higher military ranks than their guards, and they were allowed to maintain these ranks also during their time in prison.

Why these people were brought to a small village in the forest outside Perm and isolated there is still not quite clear. Archival evidence is still very limited and the main sources of information are documents from party meetings of the camp employees during that period (Obukhov 2015). According to these reports, the regime in the camp was rather mild and the prisoners lived in privileged conditions - if compared to other, ordinary prisoners.

The situation changed during the 196os when many older prisoners were released, partly due to the regular end of their sentences and partly due to an amnesty in 1968. Nevertheless, the number of prisoners in the camp still exceeded 600 at that time (Obukhov 2015, 138).

Among the newcomers in the late 1960 s were, for example, two men sentenced for their alleged participation in an attempt to assassinate Leonid Brezhnev, the leader of the Communist Party of the Soviet Union, carried out in 
Red Square in Moscow in January 1969. The two prisoners were acquaintances of the unsuccessful main assassin, Lieutenant Viktor Ilyin.

Also the third and final period of the camp's existence was unique. After 1972, some of the best-known Soviet dissidents, such as the human rights activist Sergei Kovalev, the writer Leonid Borodin, and the Ukrainian poet Vasyl Stus, were imprisoned here for their "anti-Soviet" activities. Vasyl Stus, who served a ten-year sentence in Perm-36 in the 1980s, was nominated for the Nobel Prize in Literature by the German writer Heinrich Böll in 1985, but died in the camp the same year. Other globally known people who served at least parts of their sentences in the Perm area were Nathan Sharansky, Vladimir Bukovsky, and Anatolii Marchenko.

In 1992, a non-governmental organization started a successful project to turn the former Perm-36 camp into a museum of the Gulag. The museum was established in 1994 and officially opened on September 5, 1995. Its area includes about 20 buildings and occupies 4,855 square meters. The museum's narrative does not limit its attention to the times of Stalinism. The focus on the Soviet dissidents from the 1970 indicates the museum's emphasis on the continuous character of Soviet state repressions, including during the Brezhnev period. On the other hand, this period has increasingly been seen as a period of "stability and plenitude" in post-Soviet Russia, especially during the presidency of Vladimir Putin (Fainberg and Kalinovsky 2016).

The unique character of this site was recognized both by ICOMOS, the International Council on Monuments and Sites, which is a global non-governmental organization for the conservation and protection of places of cultural heritage, and by UNESCO. In 2004, UNESCO included Perm-36 on the list of 100 World Monuments Watch memorials in order to "provide an opportunity to attract visibility, raise public awareness, foster local engagement in protection, leverage new resources for conservation, advance innovation, and demonstrate effective solutions" (World Monument Fund n.d.). There were even discussions about how to increase the status of the museum from regional to federal, although they met with the obstacle of economic authorities not wanting to provide sufficient economic help that such a change would require. Nevertheless, the museum was reconstructed by other means even though its status officially did not change (Shmyrov and Kursina 2014).

During the years when Dmitrii Medvedev was president of Russia, the Perm36 museum was in the process of being added to the Unesco World Heritage list. Despite its regional status, it was recognized as a museum of international importance, partly subsidized by the Russian state, partly financed by foreign grants. 
Things began to change in 2012, right after the return of Vladimir Putin to the Kremlin, when a new governor was appointed to the Perm area. The existing international connections were cut, and after the Russian annexation of Crimea the Russian state took full control over the museum. Perm-36 started to change in two particular ways.

Firstly, one part of the permanent exhibition was closed since it allegedly glorified human rights activists, anti-Russian nationalists, and dissidents, i.e. those who actively fought against the Soviet regime during the postwar period. Its so-called glorification of dissidents from other former Soviet republics was especially criticized. The NGO that previously handled issues concerning the memory of the Gulag at Perm-36, ANO Perm-36, was labeled a "foreign agent", part of the so-called "Fifth Column", i.e. as an organization hostile to the Russian state and representing interests of foreign - Western - powers. ${ }^{21}$ The exhibition was reorganized in a way that prevented the promotion of sympathy for those who had opposed the Soviet regime, especially after the fall of the Stalinist regime in the Soviet Union. Thus, the museum narrative lost its connections with liberal political values and human rights agenda concerning both the Soviet and Russian post-Soviet context. While the founders claim that the character of the new exhibition is supposed to present the museum as an organic part of the "normal" Soviet penal system that acted only against "criminals" and not ordinary citizens, the representatives of the new official course do not agree, claiming that the interpretation of the character of the repressions is not radically changed but only "corrected from previous mistakes" (Киктенко 2016). ${ }^{22}$ Nevertheless, the current anti-liberal tone has been evident even outside the museum. The organizers of the conference "Gulag: Echo of the War and Victory", held in October 2016 at Perm-36, for example, stressed the importance of connecting new research into the topics in question with the new State Policy to Perpetuate the Memory of Victims of Political Repressions. ${ }^{23}$ In this way, the "new" research is supposed to correspond with the quest for Russian patriotism in accordance with the government's line. Moreover, the main topics of the conference, according to the official website of the Perm region (2016), were "the contribution of the Gulag prisoners to the Victory in the Great Patriotic War and their participation in postwar reconstruction of the Soviet Union." In connection with the conference, the exhibition was further modified (Perm visitor website 2016). Although this did not mean that the partici-

21 In 2016, ANo Perm-36 was definitively forced to close down its activities.

22 See also Shmyrov (2016), and Kantor (2016).

23 Labirint. Zhurnal sotsial'no-gumanitarnykh issledovanii, <http://journal-labirint.com/? $\mathrm{p}=6354>$. 
pants automatically accepted the direction indicated by the organizers, the conference followed another controversial step made by the new museum to present the Gulag as an at least partly positive contribution to Soviet history (ru.rfi.fr 2016). Earlier the same year, in April 2016, the museum had published a booklet about the positive and "efficient" contribution of the Gulag to Soviet science, which, after some protests, had been withdrawn from its website (business-class [website] 2016).

The second change in Perm- 36 was the abortion of all peripheral activities on the part of the museum. This primarily concerned the international forum "Pilorama", which could be translated as "The Sawmill" or "Power-saw Bench". The forum annually attracted thousands of people, including some wellknown Russian artists, human rights activists, and people with liberal views, who came to Perm in order to discuss the Soviet past but also to call for respect for human rights and freedom. "Pilorama" was organized yearly at Perm- 36 between 2005 and 2012.

Today, Perm-36 is losing its former importance as a place dedicated to education about human rights and increased knowledge of the crimes of Stalinist terror. Prior to the most recent changes, Perm- 36 was visited by a total of $30,000-40,000$ visitors annually. This is a figure similar to those of Butovo and other sites of the Gulag memory in Russia. The importance of Perm-36 as a symbol, however, has been much greater in current Russian media and the entire Russian historical culture. The national media controlled by the central authorities found it necessary to organize a campaign in order to condemn the liberally oriented activities of the museum's founders. ${ }^{24}$

Due to its geographical location, some judicial proceedings connected with current changes, and the lack of access to documents, Perm- 36 remains one of the least-examined sites of memory of the crimes of Stalinism in Russia today. The developments from 2012 onwards clearly show an effort to limit the importance of this site and to deprive it of the chance to become a place that provokes a debate about the situation and role of political prisoners in regimes based on terror, or about the importance of the Soviet dissidents - from both Russia and other former Soviet republics - in the development of a civil society in Russia. As sites of memory - monuments and museums - represent the "hardware" of traumatic memory, the lack of such places paralyzes cultural debates over the need to revive and reinspire that memory, making it impossible

24 "Fifth Column." NTV, TV documentary, 2014. <http://www.ntv.ru/video/849280/> (accessed 2 March 2018). The analysis of the Russian media debate about the sites of memory connected to the Gulag in general and to Perm- 36 in particular would, however, require a specific study and is not the main task of this text. 
to reach a consensus about the past. As Alexander Etkind (2013, 246) has pointed out, memory without memorials is vulnerable to a cynical, recurrent process of refutations and denials. Feelings of guilt can be assuaged and soothed by new voices, and even the most influential texts can be challenged by new texts.

\section{Conclusion}

The Russian state still lacks a consistent official commemoration policy for the crimes of the communist dictatorship, especially with regard to the Stalin period. The situation is confusing. In 2015, the Russian government published its plan to deal with this memory, which could be partly understood as positive since previous governments have paid very little attention to this subject. At the same time, the main direction of the Gulag memory has been developing in a much more centralized way than before. Clearly defined conclusions as to how to create a modern post-communist narrative critical to the Soviet dictatorial past are still missing, despite the fact that Russian President Vladimir Putin recently issued a decree to build a new memorial to the victims of the crimes of the Stalinist regime in the Russian capital of Moscow. ${ }^{25}$

The situation at the sites of memory indicates that the attitude of the relevant Russian authorities is anti-liberal and anti-Western. While the authorities did not initiate the establishment of Butovo, the Gulag museum in Moscow, or Perm- 36 as sites of memory of the Soviet communist terror, and while they were initially highly ignorant of them, today the authorities are attempting to strengthen their control over the narratives and activities in these places. At the same time, former Western support to these sites, which contributed in large part to the possibility of preserving and developing a number of them, is now presented as very negative, as a kind of "intellectual invasion" that the West conducted through its "foreign agents" in Russia. Thus, none of these sites is allowed to make attempts to construct and present a sense of the Gulag history that could stress the individual responsibility of the visitors in order to promote democratic values based on individual human rights, i.e. to challenge the model of centralized state power in Russia. The memory of the Gulag is accepted if left as a closed chapter of the Russian/Soviet past or interpreted in a way that does not challenge the interests of the current rulers. If it challenges an organized and predominantly top-down interpretation accepted by the authorities, it is severely criticized and/or completely silenced.

$25<$ http://static.kremlin.ru/media/acts/files/o001201509300028.pdf >. 
The Orthodox commemoration of the Gulag does not seem to experience the same issues, even though it is highly critical of the communist past. Since it shares the notion of a bright Russian future if distant from the West, and since it does not challenge the goals of the increasingly authoritarian Russian regime, it is much less "problematic" for the leadership of the state than the non-governmental organizations are. In fact, the Orthodox narrative of the Gulag is the most "patriotic" coherent and officially accepted Gulag narrative existing in present day Russia.

The current Russian regime wants to see the victims of the Gulag as victims of modernization rather than as victims of senseless terror (Etkind 2009, 193). The intensifying convergence between Russian nationalism, Orthodox belief and communist sentiment is creating a new category that portrays the victims of the Gulag as martyrs of Russian uniqueness and superiority. Such an interpretation does not refer to individual victims or losers, since it attempts to turn all former losers into martyrs who - by their sacrifice - have contributed to their country's future collective success. It allows the communists to feel less guilty and more progressive. Simultaneously, it legitimizes Orthodox supremacy in Russia and encourages nationalists and other opponents of liberal democratic values. Moreover, it does not challenge the nationalism of despair as defined by Serguei Oushakine $(2009,7)$ on the basis of his research among "ordinary Russians" belonging to various communities of people who lost in the process of post-Soviet development. On the contrary, as the patriotism of despair emerged "as an emotionally charged set of symbolic practices called upon to mediate relations among individuals, nation, and state and thus to provide communities of loss with socially meaningful subject positions," these forms of nationalization and ethnification of Russian suffering based on intensifying convergence between Russian nationalism, Orthodox belief and communist sentiment have provided the key base of support for the resurgence of Russia's national assertiveness that has become so vivid during the presidency of Vladimir Putin. The memory of the victims of the Gulag has not found any specific or prominent place here. Instead of displaying empathy for the individual victims of the Soviet communist dictatorship, the narratives belonging to the nationalism of despair have rather been transformed into ideas of national belonging.

As the historian Catherine Merridale (2001,327) has shown in her study about the Soviet and Russian "culture of death", there is no self-evident connection between the Russian experience of a tragic past - war, dictatorship, violence, and terror - and a necessity to develop a liberally oriented culture of memory. While Western historical narratives about the tragic past are molded by a specific culture in which individual creativity and freedom occupy 
dominant positions, Russian suffering and victimhood are molded by the experience of lasting aspiration to universal empire. "To speak as a former Soviet citizen and a Russian is to speak.... from a culture of endurance and heroism; it is to use the language of historical destiny, to talk (however ironically) of the audacity involved in leading the collective struggle for human liberation." Therefore, the number of people who openly object the current use of the Gulag memory mentioned above still seems to be rather limited.

Thus, the main lesson from the tragic past in the form of the message "Never again!", which has become common in Western historical thinking connected especially to the Holocaust, does not find its clear Russian parallel in the form of "Never again the Gulag!" The situation that influences the specific places in this study does not indicate a quick change of attitude among decision-makers, or among those who visit the sites or are supposed to visit them, i.e. the Russian society in general. On the other hand, the different attitudes displayed in this study can aid in the understanding of the factors that contribute to a significant number of people in today's Russia still being able to see the disappearance of the Soviet Union - rather than the violence of the state against millions of its own, as well as many foreign citizens - as their shared trauma, as their common tragedy, despite their different individual beliefs and opinions.

\section{References}

\section{Interviews Made by the Author}

Ermogen, priest in Kommunarka, 11 October, 2015.

Garkavyi, Igor'. 13 October, 2016.

Romanov, Roman. 12 October, 2015.

\section{Other References}

Adler, Nanci. 1993. Victims of Soviet Terror. The Story of the Memorial Movement. Westpoint: Praeger.

Adler, Nanci. 2012. Keeping Faith With The Party. Communist Believers Return from the Gulag. Bloomington \& Indianapolis: Indiana University Press.

Alexander, Jeffrey C, ed. 2004. Cultural Trauma and Collective Identity, 4. Berkeley, California: University of California Press.

Alexander, Jeffrey C. 2012. Trauma. A Social Theory. Cambridge: Polity Press.

Butovskii poligon, Kniga pamiati zhertv politicheskikh repressii. 2007. Moscow: Alzo.

Anstett, Elisabeth. 2011. Memory of political repression in post-Soviet Russia: the example of the Gulag. Online Encyclopedia of Mass Violence. Accessed September 20, 2016. 
<http://www.sciencespo.fr/mass-violence-war-massacre-resistance/en/document/ memory-political-repression-post-soviet-russia-example-gulag>.

Antonov-Ovseenko, Anton. 1981. The Time of Stalin. Portrait of Tyranny, New York: Harper \& Row Publishers, 1981.

Baranova, Olga. 2015. "Politics of Memory of the Holocaust in the Soviet Union." IWM Junior Visiting Fellows' Conferences 34, accessed February 4, 2018. <http://www.iwm. at/publications/5-junior-visiting-fellows-conferences/vol-xxxiv/politics-of-memory-of-theholocaust-in-the-soviet-union/>.

Bogumił, Zuzanna. 2012a. Pamięć Gulagu. Kraków: Universitas.

Bogumil, Zuzanna. 2012b. "Stone, Cross and Mask: Searching for Language of Commemoration of the Gulag in the Russian Federation." Polish Sociological Review 177, no. 1: 71-90.

Bogumił, Zuzanna. 2012c. "Konflikty pamięci? - o interpretacjach historii Gulagu.“ Kultura i Spoleczenstwo (April): 23-40.

Bogumil, Zuzanna, Dominique Moran, and Elly Harrowell. 2015. "Sacred or Secular? 'Memorial', the Russian Orthodox Church, and the Contested Commemoration of Soviet Repressions." Europe-Asia Studies 67, no. 9 (November): 1416-1444.

Business-class.su. 2016. "Publikatsiia «Permi-36» o roli repressii v stanovlenii sovetskoi nauki vyzvala gnev permiakov." Business-Class, April 14, 2016. Accessed February 3, 2018. <http://www.business-class.su/news/2016/04/13/publikaciya-permi-36-o-rolirepressiy-v-stanovlenii-sovetskoy-nauki-vyzvala-gnev-permyakov>.

Cohen, Stephen F. 2012. The Victims Return. Survivors of the Gulag After Stalin. London \& New York: I.B. Taurus.

Cohen, Stephen, 2010. The Victims Return. Survivors of the Gulag after Stalin, London \& New York: I.B. Tauris.

Dorman, Veronica. 2010. "From the Solovki to Butovo: How the Russian Orthodox Church Appropriates the Memory of the Repressions." Laboratorium 2, no. 3: 431-436.

Etkind, Alexander, 2009. "Post-Soviet Hauntology: Cultural Memory of the Soviet Terror." Constellations 16, no. 1 (March): 2009. 182-200.

Etkind, Alexander. 2013. Warped Mourning. Stories of the Undead in the Land of the Unburied. Stanford: Stanford University Press.

Fainberg, Dina \& Artemy Kalinovsky. 2016. Reconsidering Stagnation in the Brezhnev Era: Ideology and Exchange. Langham: Lexington Books.

Fedor, Julie \& Sniegon, Tomas, forthcoming. The Butovskii Shooting Range: History of an Unfinished Museum. In Norris, Stephen (Ed.) Museums of Communism, Bloomington: University of Indiana Press, 2018

Gazeta.ru. 2015. "Muzej GULAG o otkrylsia v novom zdanii." Gazeta.ru, October 30, 2015. Accessed February 3, 2018. <https://www.gazeta.ru/culture/photo/otkrytie_mu zeya_gulaga_v_moskve.shtml $>$. 
Gerner, Kristian. 2011. Ryssland. En Europeisk Civilisationshistoria, Lund: Historiska Media.

Gersherson, Olga. 2013. The Phantom Holocaust. Soviet Cinema and Jewish Catastrophe. New Brunswick, N.J.: Rutgers University Press.

Gill, Graeme. 2013. Symbolism and Regime Change in Russia. New York: Cambridge University Press.

Gorin, Borukh, ed. 2013. Atlas istorii evreev v Rossi po materialam Evreiskogo muzeya $i$ Tsentra tolerantnosti. 172-202 and 238-246. Moscow: Evreiskyi muzei i Centr tolerantnosti.

Government of the Russian Federation. 2008. Kontseptsiia dolgostrochnogo sotsialnoekonomicheskogo razvitiia Rossiiskoj Federatsii na period do 2020 goda. Moscow: Federal Government Website, 2008. Accessed February 3, 2018. < http://government. $\mathrm{ru} / \mathrm{info} / 6217 />$.

Hardy, Jeffrey, forthcoming. The State Museum of Gulag History (Moscow, Russia), In Norris, Stephen (Ed.) Museums of Communism, Bloomington: University of Indiana Press, 2018

Hosking, Geoffrey. 2002. "The Second World War and Russian National Consciousness." Past \& Present 175 (May): 162-187.

Hyldal Christensen, Karin. 2016. The Making of New Martyrs of Russia. Soviet Repression in Orthodox Memory. Copenhagen: University of Copenhagen.

Ivanova, Galina. 2015. Istoriia G ULAGa, 1918-1958. Москва: ROSSPEN

Kantor, Julia. 2016. “«Perm'-36»: muzei GULAGa i Minkul'ta.” Interview by Irina Tumakova. Fontanka.ru. October 30, 2016. Accessed February 3, 2018. <http://www. fontanka.ru/2016/10/30/041/>.

Kantor, Julia. 2016. “«Perm'-36»: teper' vsio po-drugomu.” Interview by Vladimir Sokolov. Zvezda.ru, November 9, 2016. Accessed February 3, $2018<$ http://zvzda.ru/ articles/c58f3effdeb8>.

Kiktenko, Ielizaveta. 2015. "Ot pamiatnika zheertvam politicheskikh repressii do polzuchei reabilitatsii Stalina." Last modified April 14, 2015. Accessed February 3, 2018. <http://istpamyat.ru/diskussii-ocenka-novosti/aktualno/ot-pamyatnika-zhertvampoliticheskikh-repressij-do-polzuchej-reabilitacii-stalina/>.

Khlevniuk, Oleg and Simon Belokowsky, 2015. "The Gulag and the Non-Gulag as One Interrelated Whole." Kritika: Explorations in Russian and Eurasian History 16, no. 3 (Summer): 479-498.

Labirint. Zhurnal sotsial'no-gumanitarnykh issledovanii. "Vserossiiskaia nauchno-prakticheskaia konferentsiia «GULAG: ekho voiny i ekho Pobedy»". Accessed February 28, 2018. <http://journal-labirint.com/?p=6354>.

Malinova, Ol'ga. 2015. Aktual'noe proshloe: simvolicheskaia politika vlastvuiushchei elity i dilemy rossiiskoi identichnosti. Moskva: Politicheskaia entsiklopediia. 
Martyr.ru. nd. "Butovo - mesto pamiati i pokaiania." Accessed February 3, 2018. <http:// www.martyr.ru/index.php?option=com_content\&view=article\&id=156\&Item $\mathrm{id}=20>$.

McGann, Leslie. 1999. "The Russian Orthodox Church under Patriarch Aleksii II and the Russian State: An Unholy Alliance?" Demokratizatsiya, 7, no. 1: 12-27.

Merridale, Catherine. 2001. Night of Stone. Death and Memory in Twentieth Century Russia. New York: Viking Penguin.

Miller, Alexei, n.d. Iubilei 1812 goda v kontekste politiki pamiati sovremennoi Rossii. Accessed February 3, 2018. <http://www.eupress.ru/uploads/files/H-151_pages.pdf>.

Newsru.com. 2007. "Prezident Rossii pervym iz rukovodstva strany posetil mesto massovogo rasstrela repressirovannykh.” Newsru.com, December 6, 2007. Accessed February 3, $2018<$ http://newsru.com/russia/300c2007/butovo.html $>$.

NTV. "Fifth Column." Television documentary. 29.26. Accessed February 3, 2018. $<$ https://www.youtube.com/watch?v=W99YgaZ6C_o >.

Obukhov, Leonid. 2015. “«... Est' generaly, polkovniki i podpolkovniki». Istoriia kolonii dlia rabotnikov pravookhranitel'nykh organov v p. Kuchino Molotovskoi (Permskoi) oblasti. 1953-1972." In The VIII International Scientific Conference on the History of Stalinism. After Stalin. The Reforms of the 1950 in the Context of the Soviet and PostSoviet Times. Iekaterinburg, October 2015.

Oushakine, Serguei Alex. 2009. The Patriotism of Despair. Nation, War and Loss in Russia. Ithaca \& London: Cornell University Press.

Perm.ru. 2016. "V Prikam'e proidiot Vserossiiskaia nauchno-prakticheskaia konferentsiia «GULAG: ekho voiny i ekho pobedy.»" Published October 19, 2016. Accessed February 3, 2018. <http://www.perm.ru/?id=1000064\&show=33997>.

Plotnikova, Anna. 2016. “«Perm'-36»: o «belykh piatnakh» $\mathrm{i}$ «chornykh stranitsakh» istorii pod zvuky «koliuchego gimna»" GOLOS AMERIKI, October 29, 2016. Accessed February 3, 2018. <http://www.golos-ameriki.ru/a/gulag-ap/3571375.html>.

Putin, Vladimir. 2007. "Podkhod k presse posle poseshcheniia Butovskogo memorial'nogo kompleksa." Президент России (website). October 30, 2007. Accessed February 3, 2018. <http://kremlin.ru/events/president/transcripts/24627>.

Ru.rfi.fr. 2016. “Kak «podruzhit'» Den' Pobedy i Den' pamiati zhertv politicheskikh repressii." Last modified October 29, 2016. Accessed February 3, 2018. <http://ru.rfi.fr/ rossiya/20161029-kak-podruzhit-den-pobedy-i-den-pamyati-zhertv-politicheskikhrepressii >.

Rublev. 2015. "Na Butovskom poligone postroiat «Sad pamiati »." Rublev, August 7, 2015. Accessed February 3, 2018. <http://rublev.com/novosti/na-butovskom-poligonepostrojat-sad-pamjati>.

Rutland, Peter. 2014. "By Glorifying wwi, Putin Ignores Its Tragedy." The Moscow Times, August 4, 2014. Accessed February 3, 2018. <http://www.themoscowtimes.com/ opinion/article/by-glorifying-wwi-putin-ignores-its-tragedy/504549.html>. 
Samarin, Ievgenii, 2015. "Muzei istorii GULAGa otkrylsia dlia posetitelei."mos.ru, November 2, 2015. Accessed February 3, 2018. <https://www.mos.ru/news/article/273 $2073>$.

Satter, David. 2012. It Was a Long Time Ago and It Never Happened Anyway. Russia and the Communist Past. New Haven \& London: Yale University Press.

Shapovalov, V.F. 2008. "Rossiiskii patriotism i rossiiskii antipatriotizm.” Obshchestvennye nauki i sovremennost 1, 124-132.

Shmyrov, Viktor and Tatiana Kursina. 2014. Interviewed by author. September 22, 2014. Shmyrov, Viktor. 2016. “«Perm'-36». Reabilitatsiia repressii.” Zvzda.ru, December 13, 2016. Accessed February 3, 2018. <http://zvzda.ru/columns/5269ae370167>.

Smelser, Neil J. 2004. "Psychological and Cultural Trauma." In Cultural Trauma and Collective Identity, edited by Jeffrey Alexander. Cultural Trauma and Collective Identity, Berkeley, California: University of California Press.

Sovet pri Prezidente Rossiiskoi Federatsii po razvitiyu grazhdanskogo obshchestva i pravam cheloveka. "Kontseptsiia gosudarstvennoi politiki po uvekovecheniyu pamiati zhertv politicheskikh repressii." Accessed February 3, 2018. <http://president-sovet.ru/documents/read/393/\#doc-1>.

Sztompka, Piotr. 2004. "The Trauma of Social Change: A Case of Postcommunist Societies." In Cultural Trauma and Collective Identity, edited by Jeffrey Alexander. Berkeley, California: University of California Press.

Tsentral'nyj muzei Velikiy Otechestvennoi Voiny. Karta-Putevoditel'. 2010. Moscow: GuideMap Media.

Ukaz prezidenta Rossiiskoi Federatsii. O vozvedenii memoriala zhertvam politicheskikh repressii. Accessed February 28, 2018. < http://static.kremlin.ru/media/acts/files/ooo 1201509300028.pdf>.

Visitperm.ru. 2016. “«GULAG: ekho voiny i ekho pobedy.»” Published October 29, 2016. Accessed February 3, 2018. <http://www.visitperm.ru/calendar/gulag-ekho-voyny-iekho-pobedy/>.

Wood, Elisabeth. 2011. "Performing Memory: Vladimir Putin and the Celebration of World War II in Russia." The Soviet and Post-Soviet Review 38: 172-200.

World Monuments Fund. n.d. "Perm-36". World Monuments Fund (website). Accessed February 1, 2018. <https://www.wmf.org/project/perm-36>. 